\title{
CHILD AND ADOLESCENT ANXIETY IN RELATION TO THE TYPE OF FOSTER FAMILY
}

Submitted: December, 2019.

Accepted: June, 2021.

UDK: 616.891.6:364.65-053.7

DOI 10.3935/ljsr.v28i2.346

Miroslava Kojić ${ }^{1}$

https://orcid.org/0000-0002-

$7779-6540$

\section{ABSTRACT}

The aim of the study was to determine whether there are differences in the manifestation of anxiety between children and adolescents in foster families with a long history of foster care and foster families with no experience in foster care. The sample consisted of 87 respondents, 48 from foster families with a long history of foster care and 39 respondents from foster families who have just entered the foster care system. Anxiety levels were examined using the Revised Children's Manifest Anxiety Scale (RCMAS). The results showed statistically significant differences in the manifestation of anxiety between respondents from the two types of foster families. The Kruskal-Wallis test indicated statistically significant differences between respondents from foster families with a long history of foster care compared to respondents from families with no foster care experience in terms of expressing anxiety in all four subtests: a) Psychological Anxiety; b) Worry/ Hypersensitivity c) Social Anxiety and d) lie control subscale. The results of this study indicate that there are significant statistical differences between respondents living in different types of foster families. The conclusion points to the need for planned interventions that would improve the functionality of

1 Academician Miroslava Kojić, Professor (retired), e-mail: kojicmb@gmail.com

2 Zagorka Markov, PhD Special education and rehabilitation professor, e-mail: zagorka.markov@gmail.com

3 Smiljana Kojić Grandić, Graduate painter graphic artist, e-mail: smiljana59@ yahoo.com
European Academy of Sciences, Belgrade, Republic of Serbia

Zagorka Markov² https://orcid.org/0000-00027394-3195

College of Vocational Studies for the Education of Preschool Teachers, Kikinda, Republic of Serbia

Smiljana Kojić Grandić ${ }^{3}$ https://orcid.org/0000-00024342-2153

Primary School Đura Jakšić, Kikinda, Republic of Serbia

Key words:

anxiety, children and adolescents from foster families 
inexperienced foster families in their multidimensional influence on the development of children and adolescents.

\section{INTRODUCTION}

Life in a functional primary family is the right of all children because it provides children with the most humane care that reflects on their overall development (Čirjak, 2002; Škrbina, 2010). Of particular importance is the attachment to the mother, which, according to Bowlby, forms in early childhood and lasts throughout one's lifetime affecting the formation of personality (Bowlby, 1988). Findings have shown that major breaks in attachment can be followed by serious child psychopathology (Ajduković, Orešković and Laklija, 2007). Bowlby's attachment theory has been empirically tested in practice and it represents a theoretical basis in the conceptualization of modern childcare. Separation of a young child from the mother or caregiver has proved to have far-reaching consequences for the child. Bowlby argues that separation anxiety, resulting from the separation of the mother and the child for various reasons, may lead to the impairment of the child's mental health (Bowlby, 1988). Research findings show that early maladaptive behaviours and mental health problems are more prevalent in groups of respondents characterized by the insecure attachment style (Stefanović-Stanojević and Nedjeljković, 2012). This area is also important when it comes to the reasons for relocating children from their primary families (Damnjanović, 2012; Stefanović-Stanojević, 2012). That is why the child and the parents must be adequately prepared for separation (Ajduković, 1998). Bowlby argued very strongly for foster care, especially when it came to younger children (Mitić, 2002).

The most common reasons for the separation of children from their biological families, which pose the greatest developmental risks, are poverty, poor social conditions, family breakdown, lack of parental competencies, child abuse and neglect, situations in which parents disappear or abandon children, are unable to care for children, etc. (Ajduković, 2004; Žegarac and Milanović, 2014). One of the consequences of poverty is an increasing number of children with no parental care, which is one of the risks behind separating children from their families (Družić Ljubotina, Sabolić and Kletečki Radović, 2017).

The advantages of foster care in relation to institutional care can be sought in the fact that the family setting really is the natural environment for children, an environment that makes it possible for them to thrive and develop properly. Families encourage the proper emotional development of children, providing them with an understanding of what a family and its functions actually are. In foster families, 
children have the opportunity to meet their peers and expand their social network within the family in which they were placed (Sladović-Franz, 2004). Research results (Damnjanović et al., 2012) show that the quality of life of foster children and adolescents is similar to that of children from biological families.

Foster care is a special form of care outside the biological family in which the standards of care quality should resemble those in a functional biological family. A study on the opinions and experiences of children in foster families conducted in Croatia showed that children have a clear perspective on why they were placed in foster families and on the role of these families. Children prioritize foster care in relation to children's homes and believe that foster care should exist with certain changes because it benefits children without parental care. From the children's perspective, foster care is perceived as assistance and as something that is ultimately good for children without parental care (Žižak et al., 2012).

In Serbia, foster care has a history of about 85 years in several cities. About 6,500 children and adolescents are currently living in foster families (Grujić, 2013).

\section{Types of families and the their resilience needs}

According to the Ecological Theory, children's development is determined by a system of interactions within their living environment (Bronfenbrenner, 1979). The family is the first environment in which children acquire their first experiences. That is why it is important for children to grow up in healthy families. Until the inclusion of the child in the educational system, the family, as the basic building block of society, has the greatest impact on their development. A functional family is a family that is able to find ways and solutions to the problems and conflicts it encounters. A cohesive family has the capacity to support its members in various fields of life (Minić, 2009; Štalekar, 2010), i.e., it has the appropriate resources, fulfils the tasks and meets the developmental needs of its members. In contrast, dysfunctional families usually delay solving problems, i.e., tasks are not fulfilled; family members' needs are not met, etc. The dysfunctional family is in a continuous state of crisis, as it fails to recognize problems until the appearance of symptoms in its members or until a threat appears, signalling that the family system might collapse (Minić, 2009: 427).

The family is a natural social system, with its own structure, functions, rules, roles, communication methods, methods of dealing with problems and solving them. It is an organized coherent system determined by its structure (Štalekar, 2010). A functional family is able to find mechanisms by which to compensate for problems, which makes it resilient or resistant to stress. Resilience, as a dynamic process that opposes the static outcome, is very important for the survival and functioning of the family 
and its members and it contributes to the adaptation of individuals (Minić, 2009; Shiner and Masten, 2012; Yates, Tyrell, and Masten, 2014; Pavlović, Žunić-Pavlović and Glumbić, 2017). Sudden family hardships can be overcome by family resilience, e.g., long-term poverty (Jelić and Jovanović, 2011). If problems are not overcome, this can lead to extremely negative outcomes, i.e., the children can be left without parental care, so the emphasis in children's care should be on foster families (Sabolić and Vejmelka, 2015).

\section{Mental health and foster children}

Anxiety is usually described as a diffuse, unpleasant feeling of discomfort, accompanied by symptoms of the autonomic nervous system, such as headache, perspiration, palpitations, chest tightness, abdominal discomfort, restlessness that prevents prolonged standing or sitting in the same place (Borovčanin, Đukić-Dejanović and Mihajlović, 2008). Anxiety is usually assessed by evaluating its three components, i.e., behavioural, subjective and physiological symptoms (Wenar, 2003, according to Marić, 2010).

According to some research, the tendency for children from foster families to be cautious and distrustful is pronounced (Schofield and Beek, 2005), and the lack of support leads to their withdrawal, passivity, anxiety, depression, etc. (Zhang, Xiao, and $\mathrm{Gu}, 2017)$. Children in foster care are under an increased risk of many negative outcomes including emotional, behavioural, neurobiological, and social problems (Leve et al., 2012).

Research findings indicate that foster parents are also under increased stress, and one of the important factors influencing this is the behaviour of children entrusted to their care (Adams, Hassett and Lumsden, 2018). That points to the complexity of foster care as a form of care for children who, due to bad past experiences, signal the risks they were exposed to through their behaviour. The number of children placed in foster care due to negative past experiences related to emotional, physical or psychological abuse or harassment is increasing (Leve et al., 2012). Research results show that children in foster families are under a far greater risk of developing mental health disorders, compared to children and adolescents from the general population (Rubin et al., 2004; Carbone et. al., 2007; Sawyer, et al., 2002; Woods, Farineau and McWey, 2013), but that only a handful of them are in the professional support system.

Foster parents are required to have completed a foster care course to be able to react adequately in the event of emotional and behavioural problems in children (Sladović Franz, 2004). Research results show that the majority of foster parents 
are not highly educated (Ajduković et al., 2003, according to Sladović Franz; Mitić, 2002), which gives rise to a need for intensive support of foster parents implemented through various intervention programs. In the observed period of one year, children placed in families that received intensive support achieved some progress in almost all areas of life, i.e., health, intellectual development, education, emotional development and behaviour, familial and social relations, and self-protection skills. This progress is directly related to the support received (Jauković, Borisavljavić and Petrović, 2013; Ajduković, 2004).

\section{Research problem and objective}

Given that the family structure determines family processes and that family processes play a significant role in the development and functioning of children, the main objective of this research was to examine whether there are differences in the manifestation of anxiety between children and adolescents from different types of foster families.

The research problem was defined by asking the following question: Can families who have just entered foster care provide children and adolescents with conditions for proper psychological and physical development and positively influence the reduction of their anxiety?

Based on the above, the main objective of the research was defined as follows: - To determine whether there are statistically significant differences in the manifestation of anxiety between respondents placed in foster families with a long history of foster care and children placed in families with no foster care experience.

The specific objectives are:

- To determine whether there are statistically significant differences in the dimension of physiological anxiety (PA) between children placed in foster families with a long history of foster care and children placed in families with no foster care experience.

- To determine whether there are statistically significant differences in the dimension of social anxiety (SA) between children placed in foster families with a long history of foster care and children placed in families with no foster care experience.

- To determine whether there are statistically significant differences in the hypersensitivity of children placed in foster families with a long history of foster care and children placed in families with no foster care experience. 


\section{METHOD}

\section{Research sample}

The research sample consisted of 87 children and adolescents from foster families, aged 10 to 17, who attended primary and secondary schools in the territory of AP Vojvodina, in the Republic of Serbia, in the $2017 / 18$ school year. The average age of the respondents was 11.75 years. Of the total number, $52(59.8 \%)$ respondents were male and 35 (40.2\%) were female. A total of 69 respondents attended primary school (out of whom 32 attended lower grades and 37 attended upper grades), and 18 respondents attended secondary school. In accordance with the research objective, the sample was divided into two subgroups:

(a) Children and adolescents from foster families with a long history of foster care. These families included 48 children and adolescents. These respondents have been placed in foster families for the first time and have spent 2 to 5 years in foster care, without previously being in the social protection system. Bearing in mind the specific needs of children without parental care, and the conditions necessary to meet them, these children were placed in standard foster care - which meets the needs of children of orderly psychological and physical development for whom foster care has been chosen in their best interest and who have been placed in foster families for a shorter or longer period of time (Regulation on Foster Care, Off. Gazette of RS, no. 36/2008). Of the total number of respondents in this subsample, 21 have been in foster care for 1.5 to 2 years. The reason for their placement in foster care was abandonment by their biological parents due to poor financial situation. A total of 11 respondents have been in foster care for 3 years because their biological parents abandoned them to remarry, but remained in occasional contact with them. Two respondents have spent 2 years in foster care due to the death of their parents and close relatives, and 14 respondents have been in foster care for 5 years whereby the social services had no data on their biological parents. There were 29 male and 19 female respondents in this subsample. The average age of the respondents was 11.75 years.

(b) Children and adolescents from foster families with no history of foster care. These families included 39 children and adolescents. A total of 11 respondents have spent 2 years in foster care, 12 respondents have spent 3 years in foster care, and 16 respondents have spent around 5 years in foster care. Of the total number of respondents, 21 were placed in foster families due to the poor financial situation of their biological parents, 5 due to the death 
of their parents and guardian relatives, and the social services had no data on the biological families of 2 respondents. This subsample included 39 respondents (32\%). Of the total number, 23 respondents were male, and 16 were female. The average age of the respondents was 11.74 years.

\section{Measuring instrument}

The Revised Children's Manifest Anxiety Scale (RCMAS), an adaptation of the Taylor Manifest Anxiety Scale, was used to assess children's anxiety levels. A revision of the original Children's Manifest Anxiety Scale (Castaneda, Mc-Candless and Palermo, 1956), that meets psychometric criteria, was published by Reynolds and Richmond (1978) and renamed "What I Think and Feel" (WITF). Girls, on average, have slightly higher scores on this scale than boys.

The scale consists of a total of 37 items. Its structure is defined by three factors, that the authors believe confirm the view that anxiety is a multidimensional property. These factors are called: Psychological Manifestations of Anxiety (PA score, 9 items), Worry and Hypersensitivity (WH score, 10 items) and Fear and Difficulty Concentrating (SA score, 9 items). The fourth subscale is the Lie subscale which consists of 9 items ( $L$ score). Respondents gave their answers using a five-point Likert-type scale.

The reliability of the Revised Children's Manifest Anxiety Scale (Gerald and Reynolds, 1999.), in the overall survey sample, is high. The values of Cronbach's alpha for the scale as a whole and each of the subscales are as follows - for the scale as a whole 0.96, for the subscale Psychological Anxiety 0.92, for the subscale Worry/ Hypersensitivity 0.86, for the subscale Social Anxiety 0.91, and for the Lie subscale 0.65 . This finding is in line with the results of previous research and indicates the high reliability and internal consistency of the instrument used.

The research also collected basic socio-demographic data on the respondents, i.e., age, gender, place of residence, school, academic achievement, family status, length of stay in a foster family and the quality of family relations.

\section{Procedure}

Data on children and adolescents placed in foster families were obtained via an official request filed to the Social Welfare Centre, which explained the research objective, noting that the research data will be used exclusively cumulatively for scientific purposes with guaranteed respondent anonymity. It was proposed that the research be conducted in schools attended by the respondents, in the presence of expert associates and in a positive and relaxed atmosphere. 
The respondents were allowed to withdraw from the questionnaire immediately before the survey started, in line with the Code of Ethics. The importance of the research was explained to them, taking into account their age. The goals and purpose of the research, the principle of voluntariness, confidentiality and anonymity were also explained to them, and they were informed about the option to withdraw from the research at any moment.

\section{Statistical data processing}

Descriptive and comparative statistical techniques were used for the processing of the survey data. Cumulative scores were calculated for all four variables defined by the model of the Revised Children's Manifest Anxiety Scale, as follows: Physiological Anxiety - PA score (items 1, 5, 9, 13, 17,19, 21, 25, 29 and 33); Worry/Hypersensitivity - WH score (items 2, 6, 7, 10, 14, 18, 22, 26, 30, 34 and 37); Social Anxiety - SA score (items 3, 11, 15,23, 27, 31 and 35) and the control Lie scale - $L$ score (items 4, 8,12, $16,20,24,28,32,36)$. The total score on the scale was also determined by summing up the special scores, thus forming a variable Anxiety as a general assessment of the manifestation of the respondents' anxiety.

The basic descriptive statistics for the defined variables were determined as follows: minimum (Min.) and maximum (Max.) result, arithmetic mean (M), standard deviation (SD), distribution asymmetry coefficient Skewness (SK) and distribution homogeneity coefficient Kurtosis (KU). The normality of the distribution of results by groups was analysed by using the Shapiro-Wilk test (SW).

The analysis of differences between the two groups of children from different types of foster families, when it comes to social and demographic variables, i.e., gender, age, academic achievement, socioeconomic status and family relationships, was performed by using the chi-squared test and the crosstab method.

The analysis of differences between the two groups of children from different types of foster families, when it comes to the variable of manifested anxiety was performed by using the Mann-Whitney rank sum test.

The level of statistical significance of coefficients with a $5 \%$ margin of error $(p=0.05)$ was applied for all tests.

\section{RESULTS}

The analysis of basic descriptive statistics for groups of children from different types of foster families (Table 1 ) has shown that children placed in foster families with no prior foster care experience achieved, on average, higher scores on the scale 
as a whole (Anxiety), as well as on all subscale variables. A negative asymmetry of the distribution, i.e., the grouping of results in the zone of higher values for most variables, is also noticeable in this group. The platykurticity of the distribution, when it comes to the variable WH score and the total score on the scale, is also noticeable. In the group of children placed in experienced foster families, the distribution of results does not statistically significantly deviate from the normal distribution for any of the variables, while in the group of children placed in inexperienced foster families, the normality of the distribution is disturbed in case of all variables. Levene's test of variance equality showed that, in most variables, the condition of equality of variances of the analysed subsamples was violated.

In accordance with the above findings, non-parametric statistical methods were used to further analyse the differences between the two groups of children from different types of foster families.

Table 1 Descriptive statistics on the Revised Manifest Anxiety Scale for the two groups of children placed in foster families

\begin{tabular}{l|l|r|r|r|r|r|r|r}
\hline \multicolumn{2}{c|}{ Family / Variables } & Min. & Max. & M & SD & SK & KU & SWp \\
\hline \multirow{4}{*}{$\begin{array}{l}\text { Experienced } \\
\text { foster family }\end{array}$} & PA score & 9.00 & 41.00 & 23.06 & 6.21 & 0.30 & 0.23 & 0.369 \\
\cline { 2 - 9 } & WH score & 22.00 & 45.00 & 32.98 & 6.53 & 0.09 & -0.82 & 0.175 \\
\cline { 2 - 9 } & SA score & 7.00 & 31.00 & 19.17 & 5.75 & -0.08 & -0.35 & 0.670 \\
\cline { 2 - 9 } & L score & 19.00 & 42.00 & 28.98 & 5.28 & 0.37 & -0.39 & 0.350 \\
\cline { 2 - 9 } & Anxiety & 62.00 & 144.00 & 104.19 & 19.21 & 0.02 & -0.61 & 0.782 \\
\hline \multirow{4}{*}{$\begin{array}{l}\text { Inexperienced } \\
\text { foster family }\end{array}$} & PA score & 10.00 & 44.00 & 32.10 & 9.48 & -0.75 & -0.72 & 0.001 \\
\cline { 2 - 9 } & WH score & 28.00 & 53.00 & 42.31 & 8.19 & -0.51 & -1.23 & 0.001 \\
\cline { 2 - 9 } & SA score & 9.00 & 35.00 & 26.28 & 7.49 & -1.03 & 0.16 & 0.001 \\
\cline { 2 - 9 } & L score & 18.00 & 38.00 & 30.33 & 5.14 & -0.76 & 0.07 & 0.034 \\
\cline { 2 - 8 } & Anxiety & 71.00 & 165.00 & 131.03 & 28.75 & -0.71 & -0.93 & 0.001 \\
\hline
\end{tabular}

Legend: SK - skewness (asymmetry of distribution); KU - kurtosis (homogeneity of distribution); $\mathrm{SWp}$ - significance of the Shapiro-Wilks coefficient

\section{Social and demographic differences between the analyzed foster families}

The results of the analysis of differences in relation to social variables (Table 2) showed no significant differences for most variables. A statistically significant differ- 
ence was found only in relation to the variable Academic Achievement, indicating that children from experienced foster families had better academic achievements, i.e., a noticeably higher average rank than children from inexperienced foster families. In other variables, children from inexperienced foster families had higher middle ranks, but the obtained differences were not statistically significant. These families were of a somewhat poorer socio-economic status and had a lower quality of family relationships, the children practised fewer sports activities and had fewer hobbies. The average age of children from experienced and inexperienced foster families was almost identical (11.75 and 11.74 years, respectively).

Table 2 Results of analysing the differences in the manifestation of anxiety between children placed in foster families in terms of social variables 0

\begin{tabular}{|c|c|c|c|c|c|}
\hline Variables & Type of family & $\mathbf{N}$ & $\begin{array}{c}\text { Middle } \\
\text { rank }\end{array}$ & $\mathbf{Z}$ & p \\
\hline \multirow{2}{*}{$\begin{array}{l}\text { Socio-economic } \\
\text { status }\end{array}$} & Experienced foster family & 48 & 44.31 & \multirow{2}{*}{-0.15} & \multirow{2}{*}{0.878} \\
\hline & Inexperienced foster family & 39 & 43.62 & & \\
\hline \multirow{2}{*}{$\begin{array}{l}\text { Family } \\
\text { relationships }\end{array}$} & Experienced foster family & 48 & 42.60 & \multirow{2}{*}{-0.72} & \multirow{2}{*}{0.470} \\
\hline & Inexperienced foster family & 39 & 45.72 & & \\
\hline \multirow{2}{*}{ Sports } & Experienced foster family & 48 & 40.59 & \multirow{2}{*}{-1.80} & \multirow{2}{*}{0.071} \\
\hline & Inexperienced foster family & 39 & 48.19 & & \\
\hline \multirow{2}{*}{$\begin{array}{l}\text { Academic } \\
\text { Achievement }\end{array}$} & Experienced foster family & 43 & 43.21 & \multirow{2}{*}{-2.27} & \multirow{2}{*}{$0.023 *$} \\
\hline & Inexperienced foster family & 33 & 32.36 & & \\
\hline \multirow{2}{*}{ Hobbies } & Experienced foster family & 48 & 40.25 & \multirow{2}{*}{-1.80} & \multirow{2}{*}{0.072} \\
\hline & Inexperienced foster family & 39 & 48.62 & & \\
\hline
\end{tabular}

The results of the analysis of differences in the manifestation of anxiety in relation to the respondents' gender (Table 3 ) showed that statistically significant differences were not obtained in any of the variables of the subscale or in the total score on the Revised Manifest Anxiety Scale. In most variables, male respondents achieved higher mean ranks compared to female respondents, except for the variable WH score. 
Table 3 The results of analysing the differences in the manifestation of anxiety in children placed in foster families by gender

\begin{tabular}{l|l|c|c|c|c}
\hline \multicolumn{1}{c|}{ Variables } & \multicolumn{1}{c|}{ Gender } & N & Middle rank & Z & p \\
\hline \multirow{2}{*}{ PA score } & Male & 52 & 45.64 & \multirow{2}{*}{-0.74} & \multirow{2}{*}{0.459} \\
\cline { 2 - 4 } & Female & 35 & 41.56 & & \\
\hline \multirow{2}{*}{ WH score } & Male & 52 & 43.18 & \multirow{2}{*}{0.37} & \multirow{2}{*}{0.713} \\
\cline { 2 - 4 } & Female & 35 & 45.21 & & \multirow{2}{*}{0.144} \\
\hline \multirow{2}{*}{ SA score } & Male & 52 & 47.24 & \multirow{2}{*}{-1.46} & \multirow{2}{*}{0.588} \\
\cline { 2 - 4 } & Female & 35 & 39.19 & & \multirow{2}{*}{0.54} \\
\hline \multirow{2}{*}{ Anxiety } & Male & 52 & 45.20 & & \multirow{2}{*}{0.483} \\
\cline { 2 - 4 } & Female & 35 & 42.21 & & \\
\hline
\end{tabular}

Legend: Z - Mann-Whitney test coefficient Z

\section{The analysis of differences in the manifestation of anxiety in children placed in experienced and inexperienced foster families}

The results of analysing the differences in the manifestation of anxiety of children placed in experienced and inexperienced foster families (Table 4) showed statistically significant differences in all variables, except for the variable $L$ score. Children from inexperienced foster families had noticeably higher mean ranks in all subscale variables and a higher overall score on the Revised Manifest Anxiety Scale. These differences have already been observed in the analysis of the descriptive statistics of these two subsamples, where this group of children achieved higher average scores in all variables.

The obtained findings clearly point to the conclusion that children placed in inexperienced foster families are more susceptible to the manifestation of anxiety compared to children in experienced foster families. 
Table 4 The results of analysing the differences in the manifestation of anxiety in children placed in different types of foster families

\begin{tabular}{|c|c|c|c|c|}
\hline Variables & Type of family & Middle rank & Z & $\mathbf{p}$ \\
\hline \multirow{2}{*}{ PA score } & Experienced foster family & 33.16 & \multirow{2}{*}{-4.45} & \multirow{2}{*}{0.001} \\
\hline & Inexperienced foster family & 57.35 & & \\
\hline \multirow{2}{*}{ WH score } & Experienced foster family & 32.22 & \multirow{2}{*}{-4.83} & \multirow{2}{*}{0.001} \\
\hline & Inexperienced foster family & 58.50 & & \\
\hline \multirow{2}{*}{ SA score } & Experienced foster family & 32.71 & \multirow{2}{*}{-4.63} & \multirow{2}{*}{0.001} \\
\hline & Inexperienced foster family & 57.90 & & \\
\hline \multirow{2}{*}{ L score } & Experienced foster family & 40.25 & \multirow{2}{*}{-1.54} & \multirow{2}{*}{0.124} \\
\hline & Inexperienced foster family & 48.62 & & \\
\hline \multirow{2}{*}{ Anxiety } & Experienced foster family & 33.41 & \multirow{2}{*}{-4.34} & \multirow{2}{*}{0.001} \\
\hline & Inexperienced foster family & 57.04 & & \\
\hline
\end{tabular}

Legend: Z - Mann-Whitney test coefficient Z

\section{DISCUSSION}

Studies conducted in Serbia indicate that children and adolescents in the social protection system demonstrate a significantly lower level of anxiety compared to respondents placed in child care institutions and that, compared to children and adolescents from biological families, there are no statistically significant differences in terms of mental health problems, including anxiety (Damnjanović et al., 2013; Damnjanović et al., 2012). These results are in contrast with the results obtained in a study conducted in several places in Vojvodina (Kojić, Markov and Kojić Grandić, 2013). The findings of this research show that respondents placed in foster families with less experience in foster care showed greater levels of anxiety compared to children placed in families with a long history of foster care. The findings of studies conducted in other countries show that anxiety is more pronounced in children who live in foster families than in children living in biological families (Dubner and Motta, 1999; Stein et al. et al., 1999; Varni, Seid and Kurtin, 2001; Schmid et al., 2008, according to Damnjanović, 2012). The results of another study show similar results when it comes to increased levels of anxiety in children from foster care compared to those from biological families (Leve et al., 2012). Children in foster families have a far greater risk of developing mental health disorders compared to children and adolescents from the general population (Rubin, et al., 2004, Carbone, et. al., 2007; Sawyer, et. al., 2010; Woods, 2013). Similar results were obtained in another study (Turney and Wildeman, 2016). 
The separation of young children from families, their placement in foster care, and inadequate care all have a negative effect on neuroendocrine functioning. The findings of a study conducted on a sample of 55 young children placed in foster families and 104 children from biological families showed that respondents from foster families had higher incidences of atypical patterns of cortisol production (Doizer, et al., 2006), which speaks of the stress to which foster children are exposed. The findings that are in line with the above were also confirmed on a sample of 66 children aged 4 to 7 who lived in extreme poverty (Cutuli et al., 2010). Research also shows that stress can be a predictor of anxiety disorders (Oort et al., 2009). In order to preserve the cognitive development of young children living in foster families, an intervention program was designed to assist them in regulating their physiological status and behaviour (Dozier et al., 2008). Research in this area has shown that if coping mechanisms are not effective in combating gender-related stressors, the result may be chronic anxiety which may then increase the tendency towards the development of depression in women and towards the use of psychoactive substances in men (Duišin et al., 2012). Research shows a higher prevalence rate of anxiety disorders in females, but it is less known to what extent age affects the chronicity, comorbidity and course of anxiety symptoms (McLean et al., 2011). The findings of a study conducted in Serbia show that female respondents in foster families are at greater risk of developing significant anxiety and/or depressive symptoms (Damnjanović, 2012).

A longitudinal study that included 205 children and young people aged 10 to 20 concluded that respondents who showed a higher level of conscientiousness, pleasantness, openness, and a lower level of neuroticism in childhood, compared to respondents who demonstrated maladaptive behaviours, had a higher capacity for emotional regulation, a higher capacity for empathy and connection, better commitment to school obligations, etc., later in life (Shiner and Masten, 2012). Differences in the ethnic status, dialect, and place of residence between biological and foster families may cause depression and internalized behavioural problems in foster children. These are the findings of a study conducted on a sample of 106 children placed in 62 foster families (Anderson and Linares, 2012).

Some children and adolescents developed survival skills and demonstrated no problems in terms of undesirable behaviour, and have also developed an adjustment system (Schwartz, 1999), while others, due to their past trauma and lifestyle before foster care, showed a tendency towards unacceptable patterns of social behaviour.

If family relationships are considered, children from families with quality family relationships are significantly less anxious than children from families in which family relationships are mediocre or poor (Kruskal-Wallis test). Interventional support for children and foster parents provided by professional services, especially social workers, is required for children to adapt more easily to life in their new families, but also 
to minimize behavioural disorders, improve school success and academic achievement. Additional foster parent training is needed for them to be able to recognize and respond to the problems of these children (Lawrence, Carlson and Egeland, 2008.; Jauković, Borisavljević and Petrović, 2013; Rose, 2013). In this sense, the perspective of the users of interventional programs should also be considered, as a way in which they perceive themselves and the world around them, the interventional program, and the context in which the intervention is carried out (Žižak et al., 2010). Children from foster families belong to vulnerable groups, especially because they were often exposed to neglect and abuse before being placed in foster care. These children often fear that they will be displaced from their families, and this may result in behavioural problems. Foster parents should be aware of the trauma that the children have gone through, and know how to support them. A Reflexive Care Program (RFP) has been designed for children aged 4 to 11, aiming to improve foster care resources. Foster parents would be trained to support children in reaching the proper educational and socio-emotional achievements of school-age children and adolescents. In addition to foster parents, this program should also include teachers who would then be able to provide foster children with individualized academic support to improve their academic achievements and socio-emotional capacities (Redfern et. al., 2018). Children from single-parent families show poorer educational performance, which is reflected in their poorer academic achievement and school success (De Langea et al., 2014).

\section{CONCLUSION}

The structure and ability of a family to find ways to overcome problems, crises, conflicts, etc., that are encountered by all families speaks of its functionality. Due to the constant state of crisis, dysfunctional families fail to recognize the crisis symptoms that threaten family breakdown (Masten, Burt and Coatsworth, 2006; Minić, 2009; Shiner and Masten, 2012). In this sense, biological and foster families are considered functional if they respond well to the challenges of sudden adaptive problems that may arise as a result of different circumstances. The findings of a study conducted on a sample of 1,875 children and adolescents aged 10 to 14 show that family stress is a predictor of anxiety. These results are particularly affected by parental stress (Van Oort et al., 2009). A functional family is a family that is able to find ways and solutions to the problems and conflicts it encounters. It has the capacity, i.e., appropriate resources, and is able to fulfil the tasks and respond to the developmental needs of its members. In contrast, dysfunctional families usually delay solving problems, i.e., family tasks are not fulfilled, needs of family members are not met, etc. (Minić, 2009). Children and adolescents placed in foster families 
need additional support in the form of interventional programs because they are at higher risk when it comes to mental health problems, so it is necessary to strengthen their socio-emotional competencies (Männistö and Raija, 2018). These children also need individualized school support in order to improve their academic achievements and school success. Seeing that foster care is always a temporary solution and a multidimensional process, all placements in foster families are conducted from a multidimensional standpoint. Through training, foster parents are prepared for the arrival of the child, but also for their departure. Every child placed in a foster family will leave that family at one point. The Social Welfare Centre always prepares a plan for each child and assesses whether biological parents possess any parental capacities that can be worked on and improved, and the ultimate aim is always to return the child to their natural environment - their biological family. The second option is placing the child in a family of relatives who are willing to accept them and be their guardians. If none of these options can be realized, then a family is sought that can temporarily care for the child and provide them with necessary security. Foster care is temporary in character and in that sense, the capacities of the biological family should always be strengthened. The global concern about the consequences of disasters, diseases, malnutrition, abuse and other negative phenomena has led societies to start developing mechanisms of resistance to expected or unexpected threats (Berc 2012; Masten, 2014; Silberberg, 2001). In this context, functional families, as parts of society, should also strive to strengthen their resilience, because the unfavourable global situation threatens to impact the functionality of all families negatively. Expert interventions in working with families are of fundamental significance in terms of assessing the existing family potential for survival, recovery, and its strengths after the experience of stress or crisis. In that sense, all available resources should be put to use for the biological family to survive with the interventional support of social protection experts.

These research results should be interpreted with caution because, among other things, there is a relatively small number of other studies to compare the obtained findings with. However, the manifestation of anxiety is indicative and significant enough for the future of foster children, and it is necessary to examine it further. In addition to anxiety, it is also necessary to pay attention to other factors that may hinder the mental health of foster children and adolescents.

Future studies should look for more adequate ways of defining all the factors that unequivocally increase anxiety in foster children and adolescents. 


\section{REFERENCES}

1. Adams, E., Hassett, A. R. \& Lumsden, V. (2018). What do we know about the impact of stress on foster carers and contributing factors? Adoption \& Fostering, 42 (4), 338-353. https://doi.org/10.1177/0308575918799956

2. Ajduković, M. (1998). Suradnja centra za socijalnu skrb i doma za djecu u zaštiti zanemarivane i zlostavljane djece [Cooperation between the social welfare centre and the home for children in the protection of neglected and abused children]. Ljetopis Studijskog centra socijalnog rada, 5, 41-45. Retrieved from; https://hrcak.srce.hr/198508, 23.1.2019.

3. Ajduković, M. (2004). Pristupi zbrinjavanju djece bez odgovarajuće roditeljske skrbi u Europi [Approaches to caring for children without adequate parental care in Europe]. Revija za socijalnu politiku, 11 (3-4), 299-320. https://doi.org/10.3935/ rsp.v11i3.33

4. Ajduković, M., Kregar Orešković, K. \& Laklija, M. (2007). Značaj teorije privrženosti za konceptulizaciju javne skrbi za djecu [The Significance of attachment theory for the conceptualization of public children's care]. Ljetopis socijalnog rada, 14 (1), 93-118. Retrieved January 20, 2019. Retrieved February 19, 2019. from https://hrcak.srce.hr/11495

5. Anderson, L. \& Linares, O. (2012). The role of cultural dissimilarity factors on child adjustment following foster placement. Children and Youth Services Review, 34 (4), 597-601. https://doi.org/10.1016/j.childyouth.2011.11.016

6. Berc, G. (2012). Obiteljska otpornost - teorija i primjena koncepta u socijalnom radu [Family resilience - theory and application of the concept in social work]. Ljetopis socijalnog rada, 19 (1), 145-167. Retrieved from: https://hrcak.srce.hr/ 82978, 05.02.2019.

7. Borovčanin, M., Đukić-Dejanović, S. \& Mihajlović, G. (2008). Biološke osnove anksioznosti i novine u psihofarmakološkom tretmanu anksioznih poremećaja [Biological bases of anxiety and novelties in the psychopharmacological treatment of anxiety disorders]. Engrami, 30 (3-4), 53-59.

8. Bowlby, J. (1988). A secure base: Parent-child attachment and healthy human development. New York: Basic Books INC.

9. Bronfenbrenner, U. (1979). The ecology of human development, Harvard University Press.

10. Carbone, J. A., Sawyer, M. G., Searle, A. K. \& Robinson, P. J. The health-related quality of life of children and adolescents in home-based foster care. Quality of Life Research. 2007 Sep; 16 (7), 1157-66. https://doi.org/10.1007/s11136-0079227-z 
11. Castaneda, A., Palermo, D. S. \& McCandless, B. R. (1956). Complex learning and performance as a function of anxiety in children and task difficulty. Child Development, 27, 327-332. https://doi.org/10.2307/1126202

12. Čirjak, S. (2002). Porodični smeštaj dece kao oblik dečije zaštite u centru za socijalni rad [Family accommodation of children as a form of child protection in the social welfare centre]. Norma, 8 (1-2), 9-23.

13. Cutuli, J. J., Wiik, K. L., Herbers, J. E., Gunnar, M. R. \& Masten, A. S. (2010). Cortisol function among early school-aged homeless children. Psychoneuroendocrinology, 35 (6), 833-845. https://doi.org/10.1016/j.psyneuen.2009.11.008

14. Damnjanović M.V. (2012). Karakteristike kvaliteta života i mentalnog zdravlja dece i adolescenata koji su u sistemu socijalne zaštite (doktorska disertacija) [Characteristics of the quality of life and mental health of children and adolescents in the social protection system (Doctoral dissertation)]. Beograd: Medicinski fakultet. Retrieved from: fhttp://nardus.mpn.gov.rs/handle/123456789/ 2417?show=full, 05/01/2019.

15. Damnjanović, M., Lakić, A., Stevanović, D., Jovanović, A., Jančić, J., Jovanović, M. \& Leposavić, L. (2012). Samoprocena kvaliteta života dece i adolescenata u sistemu socijalne zaštite Srbije [Self-Assessment of the quality of life of children and adolescents in the Serbian social protection system]. Vojnosanitetski pregled, 69 (6), 469-474. https://doi.org/10.2298/VSP1206469D.

16. Damnjanović, M., Nenadović, M., Kuzmanović, A., Živković, Ž., Nenadović, N. \& Grbić, I. (2013). Anksiozni poremećaji dece i adolescenata u domskom smeštaju sistema socijalne zaštita [Anxiety disorders of children and adolescents in children's homes in the social protection system]. Praxis medica, 42 (3), 93-96.

17. De Langea, M., Dronkersb, J., Maarten H. J. \& Wolbersa, M.H.J. (2014). School Effectiveness and School Improvement, 25, 3, 329-350. http://dx.doi.org/10.10 80/09243453.2013.809773

18. Dozier, M., Manni, M., Gordon, M. K., Peloso, E., Gunnar, M. R., Stovall-McClough, K. C., Eldreth, D. \& Levin, S. (2006). Foster children's diurnal production of cortisol: an exploratory study. Child Maltreatment, 11 (2), 189-97. https://doi. org/10.1177/1077559505285779

19. Družić Ljubotina, O., Sabolić, T. \& Kletečki Radović, M. (2017). Život obitelji s djecom u uvjetima siromaštva iz perspektive roditelja [Family life with children in conditions of poverty from the perspective of parents]. Ljetopis socijalnog rada, 24 (2), 243-276. https://doi.org/10.3935/ljsr.v24i2.185

20. Duišin, D., Barišić, J., Milovanović, S., Nikolić-Balkoski, G. \& Pantović, M. (2012). Rodna i polna anksioznost [Gender and sexual anxiety]. Engrami, 34 (2), 35-44.

21. Gerard, A. B. \& Reynolds, C. R. (1999). "Characteristics and applications of the Revised Children's Manifest Anxiety Scale". In: Maruish, M.E. (ed.) The use of 
psychological testing for treatment and planning and outcomes assessment. Mahwah, New Jersey: Erlbaum Associates, 323-340.

22. Grujić, D. (2013). Prvih pet godina centra za porodične smeštaj i usvojenje Beograd [The first five years of the entre for family accommodation and adoption Belgrade]. In: D. Grujić (ed.), Zbornik radova za međunarodne konferencije: Izazovi hraniteljstva na početku 21. veka [Proceedings of an International Conference: Foster care challenges at the beginning of the 21 $1^{\text {st }}$ century], 16-17 December 2013, Belgrade. Beograd: Centar za porodični smeštaj dece i usvojenje, 7-21. https://doi.org/10.10170S0954579406060044 https://pediatrics.aappublications.org/content/pediatrics/138/5/e20161118. full.pdf

23. Jauković, T., Borisavljavić, T. \& Petrović, M. (2013). Hraniteljstvo uz dodatnu i intenzivnu podršku [Foster care with additional and intensive support]. In: D. Grujić (ed.), Zbornik radova za međunarodne konferencije: Izazovi hraniteljstva na početku 21. veka [Proceedings of an International Conference: Foster care challenges at the Bbeginning of the 21 $1^{\text {st }}$ century], 16-17 December 2013, Belgrade. Beograd: Centar za porodični smeštaj dece i usvojenje, 33-53.

24. Jelić, M. \& Jovanović, B. (2011). Siromaštvo kao faktor školskog neuspeha učenika [Poverty as a factor in student school failure]. Socijalna misao, 4, 79-95.

25. Kojić, M., Markov, Z. \& Kojić-Grandić, S. (2013). Anksioznost dece i adolescenata iz hraniteljskih porodica [Anxiety of children and adolescents from foster families]. Nastava i vaspitanje, 62 (4), 651-667.

26. Lawrence, C. R., Carlson, E. A. \& Egeland, B. (2008). The impact of foster care on development. Development and Psychopathology, 18 (57-76).

27. Leve, L. D., Harold, G. T., Chamberlain, P., Landsverk, J. A., Fisher, P. A. \& Vostanis, P. (2012). Practitioner review: Children in foster care-vulnerabilities and evidence-based interventions that promote resilience processes. Journal of child psychology and psychiatry, and allied disciplines, 53 (12), 1197-211. https://doi. org/10.1111/j.1469-7610.2012.02594

28. Männistö, I. I. \& Pirttimaa, R. A. (2018). A review of interventions to support the educational attainments of children and adolescents in foster care. Adoption \& Fostering, 42 (3), 266-281. https://doi.org/10.1177/0308575918791627

29. Marić, M. (2010). Osobine ličnosti, životni događaji i anksioznost adolescenata [Personality traits, life events and adolescent anxiety]. Primenjena psihologija, 3 (1), 39-57. https://doi.org/10.19090/pp.2010.1

30. Masten, A. S. (2014). Global perspectives on resilience in children and youth. Child Development, 85 (1), 6-20. https://doi.org/10.1111/cdev.12205

31. Masten, A. S., Burt, K. B. \& Coatsworth, J. D. (2006). Competence and psychopathology in development: Risk, disorder and psychopathology. In: D. Ciccheti, 
\& D. Cohen (eds.), Developmental psychopathology: Risk, disorder and psychopathology. New York: Wiley, 696-738. https://doi.org/10.1002/9780470939406. ch19

32. McLean, C. P., Asnaani, A., Litz, B. T. \& Hofmann, S. G. (2011). Gender differences in anxiety disorders: Prevalence, course of illness, comorbidity and burden of illness. Journal of psychiatric research, 45 (8), 1027-35. https://doi.org/10.1016/j. jpsychires.2011.03.006

33. Minić, J. (2009). Porodica u krizi [Family in a crisis]. Zbornik radova Filozofskog fakulteta u Prištini, (39), 425-435.

34. Mitić, M. (2002). Porodični smeštaj - hraniteljstvo kao oblik zaštite dece bez roditeljskog staranja [Family accommodation - Foster care as a form of protection of children without parental care]. In: B. Kuzmanović (Ed.). Deca bez roditeljskog staranja [Children without parental care]. Beograd: Institut za psihologiju Filozofskog fakulteta Univerziteta u Beogradu, 235-277.

35. Pavlović, M. V., Žunić-Pavlović, V. P. \& Glumbić, N. P. (2017). Komparacija individualnih kvaliteta rezilijentnosti adolescenata sa intelektualnom ometenošću i adolescenata tipičnog razvoja [Comparison of individual qualities of resilience of adolescents with intellectual disabilities and adolescents of typical development]. Nastava i vaspitanje, 66 (2), 289-304. https://doi.org/10.5937/ nasvas1702289P

36. Pravilnik o hraniteljstvu (2008). Sl. glasnik RS, 36/2008. [Regulation on foster care (2008), Off. Gazette of RS, 36/2008].

37. Redfern, S., Wood, S., Lassri, D., Cirasola, A., West, G., Austerberry, C., Luyten, P., Fonagy, P. \& Midgley, N. (2018). The reflective fostering programme: Background and development of a new approach. Adoption \& Fostering, (3), 234-248. https://doi.org/10.1177/0308575918790434

38. Reynolds, C. R. \& Richmond, B. O. (1978). What I think and feel: A revised measure of children's manifest anxiety. Journal of Abnormal Child Psychology, 6 (2), 271-280. https://doi.org/10.1007/BF00919131

39. Rose, J. (2013). Društvena zaštita u privatnoj službi-staranje o tuđoj deci pod okriljem vlastitog doma [Social protection in private service - Caring for other people's children under the auspices of one's own home]. In: D. Grujić (ed.), Zbornik radova za međunarodne konferencije: Izazovi hraniteljstva na početku 21. veka [Proceedings of an International Conference: Foster care challenges at the beginning of the 21 $1^{\text {st }}$ century], 16-17 December 2013, Belgrade. Beograd: Centar za porodični smeštaj dece i usvojenje, 107-116.

40. Rubin, D. M., Alessandrini, E.A., Feudtner, C., Mandell, D. S., Localio, A. R. \& Hadley, T. (2004). Placement stability and mental health costs for children in foster care. Pediatrics, 113 (5), 1336-41. 
41. Sabolić, T. \& Vejmelka, L. (2015). Udomiteljstvo djece u Hrvatskoj iz perspektive udomitelja i stručnjaka [Foster care of children in croatia from the perspective of foster parents and experts]. Holon, 5 (1), 6-42. Retrieved from: https://hrcak. srce.hr/140394, 17.3.2019.

42. Sawyer M. G., Whaites L., Rey J. M., Hazell P. L., Graetz B. W. \& Baghurst P. (2002). Health-related quality of life of children and adolescents with mental disorders. Journal of American Academy of Child and Adolescent Psychiatry, 41, 530-537. https://doi.org/10.1097/00004583-200205000-00010

43. Schofield, G. \& Beek, M. (2005). Risk and resilience in long-term foster-care. The British Journal of Social Work, 35 (8), 1283-1301. https://doi.org/10.1093/ bjsw/bch213

44. Schwartz, W. (1999). School support for foster families. ERIC/CUE Digest, Number 147. https://files.eric.ed.gov/fulltext/ED434189.pdf

45. Shiner, R. L. \& Masten, A. S. (2012). Childhood personality as a harbinger of competence and resilience in adulthood. Development and Psychopathology, 24(2), 507-528. https://doi.org/10.1017/S0954579412000120

46. Silberberg, S. (2001). Searching for family resilience. Searching for family resilience, 58, 52-57. https://aifs.gov.au/sites/default/files/ss\%283\%29.pdf

47. Škrbina, D. (2010). Podrška udomitelja koji udomljavaju djecu s Down sindromom [Support for foster parents who adopt children with Down syndrome]. Život $i$ škola, LVI (23), 9-34. Retrieved from: https://hrcak.srce.hr/53934, 26.2.201.

48. Sladović Franz, B. (2004). Odabir izvanobiteljskog smeštaja djece ugroženog razvoja u obitelji [Choice of Out-of-Home Accommodation for Children with Disabilities in the Family]. Ljetopis socijalnog rada, 11 (2), 215-228. Retrieved from: https://hrcak.srce.hr/3387, 20.2.2019.

49. Štalekar, V. (2010). Dinamika obitelji i prvi teorijski koncepti [Family Dynamics and the First Theoretical Concepts]. Medicina Fluminensis, 46 (3), 242-246. Retrieved from: https://hrcak.srce.hr/59246, 25.1.2019.

50. Stefanović Stanojević, T. (2012). Teorija afektivne vezanosti: Okvir u savetodavnom radu sa porodicama [Affective attachment theory: A framework in counseling work with families]. In: Živančević Sekreuš I. (ed.), Mogućnosti primene teorije afektivne vezanosti u savetodavnom radu sa porodicama [Possibilities of applying the theory of afective attachment in counseling work with families]. Novi Sad: Filozofski fakultet - odsek za psihologiju, 8-21.

51. Stefanović Stanojević, T. \& Nedjeljković, J. (2012). Attachment patterns from the perspective of early maladaptive schemas. Ljetopis socijalnog rada, 19 (1), 95-118. Retrieved from: https://hrcak.srce.hr/82949, 18.3.2019.

52. Turney, K. \& Wildeman, C. (2016). Mental and physical health of children in foster care. Pediatrics, 138 (5); https://doi.org/10.1542/peds.2016-1118 
53. Van Oort, F. V., Verhulst, F. C., Ormel, J. \& Huizink, A. C. (2009). Prospective community study of family stress and anxiety in (pre)adolescents: The TRAILS study. European child \& adolescent psychiatry, 19(6), 483-91. https://doi.org/10.1007/ s00787-009-0058-z

54. Yates, T.M., Tyrell, F. \& Masten, A.S. (2014). Resilience theory and the practice of positive psychology from individuals to societies. In: Joseph, s. (ed.), Positive psychology in practice: Promoting human flourishing in work, health, education, and everyday life. New Jersey: Wiley\&Sons, 773-788. Available at: https:// adlab.ucr.edu/wp-content/uploads/2016/09/Yates-Tyrell-Masten-2015-Published-Copy.pdf, 18.3.2019.

55. Žegarac, D. \& Milanović, D. (2014). Istraživanje uzroka smeštaja, procesa donošenja odluka i ishoda za decu na porodičnom i rezidencijalnom smeštaju [Research on the causes of accommodation, decision-making processes and outcomes for children in family and residential accommodation]. In: Žegarac, D. (ed.), U lavirintu socijalne zaštite [In the labyrinth of social protection]. Beograd: Fakultet političkih nauka, Univerzitet u Beogradu, 125-215.

56. Zhang, F., Xiao, L. \& Gu, R. (2017). Does gender matter in the relationship between anxiety and decision-making? Frontiers in psychology, 8, 2231. https:// doi.org/10.3389/fpsyg.2017.02231

57. Žižak, A., Koller-Trbović, N., Jeđud Borić, I., Maurović, I., Mirosavljević, A. \& Ratkajec Gašević, G, (2012). Što nam djeca govore o udomiteljstvu-Istraživanje dječje perspektive udomiteljstva u Hrvatskoj s preporukama za unapredjenje [What children are telling us about foster Care - Research of Children's Perspective of Foster Care in Croatia With recommendations for improvement]. Zagreb: Ured UNICEF-a za Hrvatsku.

58. Žižak, A., Maurović, I. \& Jeđud, I. (2010). Povezanost procjene rizika s osobnim, obiteljskim i drugim obilježjima maloljetica, korisnica različitih tretmanskih programa [Association of risk assessment with personal, family and other characteristics of minors, beneficiaries of various treatment programs]. Kriminologija \& socijalna integracija, 18 (2), 29-44. Retrieved from: https://hrcak.srce. $\mathrm{hr} / 62468,19.3 .2019$.

59. Woods S. B., Farineau H. M. \& McWey, L. M. (2013). Physical health, mental health, and behaviour problems among early adolescents in foster care. Child Care Health Development, 39 (2), 220-7. https://doi.org/10.1111/j.13652214.2011.01357.x. 
Miroslava Kojić

Zagorka Markov

Smiljana Kojić Grandić

\section{ANKSIOZNOST DJECE I ADOLESCENATA U ODNOSU NA VRSTU UDOMITELJSKE OBITELJI}

\section{SAŽETAK}

Cilj istraživanja bio je utvrditi postoje li razlike u pojavi anksioznosti između djece i adolescenata u udomiteljskim obiteljima s dugotrajnim udomiteljskim iskustvom i udomiteljskih obitelji bez prethodnog udomiteljskog iskustva. U istraživanju je sudjelovalo 87 ispitanika, 48 iz udomiteljskih obitelji s dugotrajnim udomiteljskim iskustvom i 39 iz udomiteljskih obitelji koje su tek ušle u sustav udomiteljstva. Stupnjevi anksioznosti ispitani su uz pomoć Prerađene dječje skale anksioznosti (Revised Children's Manifest Anxiety Scale - RCMAS). Rezultati ukazuju na statistički značajne razlike u pojavi anksioznosti između ispitanika iz dvije vrste udomiteljskih obitelji. Kruskal-Wallis test upućuje na statistički značajne razlike između ispitanika iz udomiteljskih obitelji $s$ dugotrajnim udomiteljskim iskustvom u usporedbi s ispitanicima iz udomiteljskih obitelji bez prethodnog udomiteljskog iskustva u smislu iskazivanja anksioznosti u sva četiri podtesta: a) psihološka anksioznost; b) zabrinutost/hiperosjetljivost, c) socijalna anksioznost i skala kontrole laži. Rezultati istraživanja pokazuju da postoje značajne statističke razlike između ispitanika koji žive u različitim vrstama udomiteljskih obitelji. Zaključak ukazuje na potrebu za planiranim intervencijama koje bi poboljšale funkcionalnost neiskusnih udomiteljskih obitelji u njihovom multidimenzionalnom utjecaju na razvoj djece i adolescenata.

Ključne riječi: anksioznost; djeca i adolescenti iz udomiteljskih obitelji

\section{(i) $(9$}

Međunarodna licenca / International License:

Creative Commons Attribution-NonCommercial-NoDerivatives 4.0. 